\section{AIDS and hepatitis: a guide for obstetrical anaesthetists}

Whenever a patient with an acute viral infection is anaesthetised, several problems must be considered. Firstly, what are the risks to the patient? Secondly, what can be done to minimize these risks? Thirdly, can the spread of the disease to medical personnel and other patients be prevented? Currently, the acute viral infections which are of most concern are AIDS and hepatitis and these will be considered in greater detail.

\section{Acquired immune deficiency syndrome (AIDS)}

AIDS is an incurable, ultimately fatal disease characterized by a severe reduction of cell-mediated immunity, primarily affecting helper T-lymphocytes. ${ }^{1-4}$ AIDS is caused by a virus knuwn by several names in the medical literature. These include Human T-Cell Lymphotropic Virus (HTLV-II), Lymphadenopathy Associated Virus (LAV), AIDS Associated Retro Virus (ARV), and Human lmmunodefficiency Virus (HIV), A recent international committce on taxonomy of viruses has proposed the latter name. A few weeks after infection, the patient becomes viremic and seroconversion to HIV antibody occurs. This is then followed by an asymptomatic period of months or years. The virus has a long incubation period and it is not known for certain what percentage of people infected with the HIV virus will develop AIDS. When associated with transfusions, the median incubation period appears to be 29 months for adults and 14 months for infants, ${ }^{5}$ but AIDS has been documented to occur up to $5 \frac{1}{2}$ years after a transfusion. ${ }^{6}$ For infected homosexual men, 5 to 20 per cent will develop AIDS within two to five years after infection. ${ }^{7}$ However, many infected people remain asymptomatic. Patients are prone to recurrent opportunistic infections, which may be protozoan, fungal or viral. In addition unusual malignancies, such as Karposi's sarcoma and non-Hodgkin's lymphoma often develop.

AIDS seems most likely to occur in homosexual or bisexual men.' Intravenous drug abusers and patients receiving multiple blood transfusions or blood products are also at increased risk. Most recently the syndrome has been reported in spouses of members of high risk groups and in those with promiscuous heterosexual behaviour. Children of infected mothers are also at risk. In 1985 a blood test specific for antibodies against HIV was developed. The American Food and Drug Agency li- cenced the first enzyme-linked immunoabsorbent assay, the ELISA or EIA test. The preliminary estimate of positive tests for both ELISA or EIA and Western Blot Analysis (a second more sensitive test) was 38 per 100,000 American Red Cross blood donors. ${ }^{8}$ The risk of a patient in the United States receiving AIDS-infected blood is estimated to be 3.8 per million units, i.e. a very low risk. ${ }^{8}$

What are the risks to health care workers? Only $2 / 1785$ reports of people exposed to a needle or body fluids of an infected patient were antibody positive in follow-up. , $^{9}$ However, only a few hundred health care workers have been followed for three years. Thus, since the virus has a low infectivity rate, health care workers should be concerned but not alarmed ${ }^{1.9 .10}$ Asymptomatic patients with positive serology and patients with overt disease should be managed in the same way. All hospital staff should take the precautions outline below when handling body fluids. Currently 0.5 per cent of patients will be infected with the AIDS virus and most of these are asymptomatic and undiagnosed. This is obviously very important to any anaesthetist or health care worker because of the potential to infect patients, should he or she become infected with the HIV virus.

The following guidelines were issued by the Center for Disease Control, Atlanta on November 15, $1985 .{ }^{9.11}$ Sharp needles should not be recapped, bent, broken or removed from disposable syringes before being discarded into puncture resistant containers. Gloves may be protective enough if one is only handling infected objects but gown, mask and goggles are suggested if more extensive contact with body fluids is expected. If hands become contaminated, they should be washed immediately. Sterilization of equipment is adequate for most items. ${ }^{1-4}$ Laryngoscope blades, temperature probes and oesophageal stethoscopes should be cleaned with sodium hypochlorite (household bleach diluted 1: 10 to 1: 1000), which is very effective against the AIDS virus. Gas or steam autoclaving will also inactivate the AIDS virus. Many anaesthetic departments in the United States which deal with large numbers of HIV-infected patients use disposable circuits and occasionally disposable carbon dioxide absorbers. ${ }^{12}$ While it is true that bacteria can survive and grow in an anaesthetic circuit, a virus will not grow outside a host organism. Thus the argument for use of disposable anaesthestic equipment to prevent spread of viruses is speculative at best.

\section{Anaesthesia in obstetric patients with AIDS}

Few Canadian anaesthetists are now likely to treat a pregnant woman who is a carrier for the AIDS virus, but the number of cases is increasing. ${ }^{13-16}$ The viral agent preferentially attacks not only helper cells but also cells in the brain. ${ }^{17}$ About 20 per eent of patients with AIDS 
develop vacuolar degeneration of the spinal cord with associated paraparesis, ataxia and incontinence. Approximately 33 per cent develop a subacute encephalitis, often leading to dementia, coma and death. Neurologic symptoms may precede the opportunistic infections and malignancies which are part of the definition of AIDS.

The virus may exist for long periods of time in an inactive state within the host cell. It is poorly understood as to what factors cause its conversion to an active state and resulting rapid and severe damage to the host cell. Anaesthetists generally prefer not to use epidural or subarachnoid anaesthesia in patients with active or potentially progressive spinal cord lesions. ${ }^{18}$ Such disorders are being diagnosed in an increasing number of patients with AIDS. Because of this, a careful decision must be made before proceeding with regional anaesthesia because of the possibility of subsequent development of neurological problems in patients with inactive disease. Anaesthetists should be aware of this information and discuss possible risks and benefits with each patient.

\section{Hepatitis}

Although all forms of liver disease can affect pregnant women, viral hepatitis is the most common. The various agents lead to an acute and similar phase of hepatitis; which may range from a very mild illness to fulminant liver failure. ${ }^{19.20}$ Treatment consists of hospitalizing all pregnant women with suspected hepatitis until they can eat and drink and liver function does not continue to deteriorate. ${ }^{21}$ The basis of all treatments is rest and a nutritious diet.

Viral Hepatitis A was formerly referred to as "infectious" hepatitis. ${ }^{19,21}$ This name is incorrect since both "infectious" and "serum" bepatitis can be transmitted by either the oral or parenteral route. The hepatitis A virus is shed in the faeces of patients developing the disease and is usually spread by blood or water. During a brief period of viraemia, the blood is also infectious. Hepatitis A has an incubation period of two to seven weeks, and presents with nonspecific signs and symptoms, which often are not diagnosed until the patient becomes jaundiced. The diagnosis is confirmed by measuring Hepatitis $A$ antibody but this test is not routinely available. ${ }^{20}$ Hepatitis caused by the $\mathrm{A}$ virus, cytomegalic vinus and Epstein-Barr vinus all present with a similar range of clinical symptoms. All three do not usually go on to a chronic phase and are transmissible only in the acute phase. ${ }^{22}$

Viral hepatitis has been previously referred to as "serum" hepatitis. ${ }^{21}$ It is usually, but not always, transmitted by blood or blood products and in body secretions. ${ }^{19,21}$ As a result it is more common in drug abusers, homosexuals, health care workers and haemophiliacs. Hepatitis $\mathrm{B}$ antigen is found in 83 per cent of patients tested within
12 days of onset of symptoms but usually clears by three to four weeks. Non-A non-B hepatitis has become the most common form of post-transfusion hepatitis. ${ }^{21}$

\section{Anaesthetic considerations for patients with hepatitis} The main objective in anaesthetizing a patient with hepatitis is to avoid making the hepatic disease worse and thus increasing the chance of associated renal failure and death. ${ }^{23}$ All anaesthetic drugs and techniques (general, spinal or epidural) may cause transient abnormality of liver function tests. ${ }^{20,23,24}$ These abnormalities are worse after upper abdominal surgery and are believed due to a decrease of hepatic blood flow. ${ }^{23}$ Other factors predisposing to abnormal postoperative liver function are preexisting disease, hypokalaemia, hypotension, sepsis and transfusions. ${ }^{23}$

As far as is known, none of the currently used intravenous or inhalation anaesthetic drugs cause liver cell damage by direct toxic effect. Instead, the decreased hepatic blood flow is believed to decrease oxygen delivery and results in reductive or anaerobic metabolism occurring in the liver cell. Reductive metabolites of halothane have been implicated as potential hepatotoxins. ${ }^{20,23}$ Thus the importance of maintaining adequate hepatic oxygenation with adequate blood flow has special significance during halothane anaesthesia. Decreased hepatic blood flow also results in decreased delivery of drugs to the liver and may increase drug effects. ${ }^{20,23}$ Any anaesthetic or surgery is associated with a high incidence of death from liver failure if the patient has acute viral hepatitis. There are no adequate studies which show how to decrease this risk in patients with abnormal hepatic function. Any intravenous or inhalational anaesthetic may be used. Likewise, general and regional anaesthesia may be used.

Finally, how does one protect other patients and the hospital staff (including the anaesthetist) from infection? Current recommendations, as for patients with AIDS, apply also to patients with hepatitis. In addition, maintaining a high index of clinical suspicion and consideration of hepatitis vaccine will help prevent infection. ${ }^{22}$

In summary, viral infections are a concern both to the public and to physicians. By following the principles described above, anaesthetists can protect themselves and their patients and still continue to provide patients with the best standard of care available.

\section{References}

1 Kunkel SE, Warner NA. Human T-Cell lymphotropic virus type III (HTLV-III) infection: how it can affect you, your patients and your anesthesia practice, Anesthesialogy 1987; 66: $195-207$. 
2 Cordero AS, Bonner JT, Brynes RK. AIDS and the anaesthetist. Can Anaesth Soc J 1985; 32: 45-8.

3 Greene $E R$. Acquircd immunodefficiency syndrome: an overview for anesthesiologists. Anesth Analg 1986; 65: 1054-8.

4 Lee KG. SoniN. AIDS and anaesthesia. Anaesthesia 1986; 41: $1011-16$

5 Feorino PM, Jaffe HW, Palmer E et al. Transfusion associared acquired immunodeficienc y syndrome: evidence for persistent infection in blood donors. N Engl J Med 1985; 312: $1293-6$.

6 Maloney MJ, Cox F, Wray BB, Guill MF, HaglerJ. AlDS in a child $5 \frac{1}{2}$ years after transfusion. N Engl J Med 1985; 312: 1256-7.

7 Curran JW. The epidemiology and prevention of acquired immunodeficiency syndrome. Ann Int Med 1985; 103: $657-62$.

8 Schorr JB, Berkowizz A, Cumming PD, Katz AJ, Sandler $S G$. Prevalence of HTLV-III in American blood donors. N Engl J Med 1985; 313: 384-5

9 AIDS and Health Care Workers. Ministry of Health, Toronto, Ontario, Canada, Fall 1986.

10 Update: Human immunodeficiency virus infections in health-care workers exposed to blood of infected patients United States. Canada Diseases Weekdy Report. Hcalth and Welfare Canada, May 30, 1987; 95-8.

11 Sumurary: recommendations for preventing transmission of infection with hunan T-lymphotropic virus type IIL lymphadenopathy-associated vins in the workplace. Atlanta. Georgia: Center for Disease Control; MMWR $1985 ; 254: 3162-7$.

12 Arden $J$. Anesthetic management of patients with AIDS. Anesthesiology 1986; 64: 660-1.

13 Minkoff HL, Schwarz RH. AIDS: Time for obstetricians to get involved. Obstet Gynecol 1986; 68: 267-8.

14 Quaggin A. Get prepared for more cases of AIDS during pregnancy, Can Med Assoc J 1987; 136: 192-3.

15 Scon GB, Fischl MA, Klimas $N$ et ai. Mothers of infants with acquired immunodeficiency syndrome. JAMA 1985 252: 363-6.

16 Weber DS, Redfield RR, Leman SM. Acquired immunodcficiency syndrome: epidemiology and significance for the obstetrician and gynecologist. Obstet Gynecol 1986; 155: 235-40.

17 Ho DM. Pomerantz RJ, Kaplan JC. Pathogenesis of infection with human immunodeficiency virus. $N$ Engl $J$ Med 1987; 317: 278-86.

18 Greene ER. Spinal and epidural anesthesia in patients wilh acquired immunodefieiency syndrome. Anesth Analg 1986; 65: 1089-93.

19 Pritchard JA, MaCDonald PC, Gant NF. Medical and surgical illnesses during pregnancy and the puerperium. In: Williams Obstetrics, 17 th edition. Connecticut:
Appleton-Century Crofts, 1985: 614-5.

20 Maze $M$, Baden JM. Anesthesia for patients with liver disease. In: Miller RD (Ed). Anesthesia, 2nd edition. New York: Churchill Liwingstone Inc, 1986: 1665-80.

21 Douvas SF, Meeks GR, Philips $J$ et al. Liver disease in pregnancy. Obstet and Gynccol Survey 1983; 38:53 J-6.

22 Mathieu A Dienstag JL. The hazard of viral hepatitis to anesthesiologists and other operating room rersonncl. $n$ : Orkin FK, Connernan LH (Eds). Complications in Anesthesiology. Philadelphia: JB Lippincott, 1983: 697-705.

23 Roizen $M F$. Anesthetic implications of concurrent diseases. In: Miller RD (Ed). Anesthesia, 2nd edition. New York: Churchill Livingstone Inc, 1986: 317-19.

24 Schemel $W H$. Unexpected hepatic dysfunction found by multiple laboratory screening. Anesth Analg 1976; 55: 810-2.

\section{Herpes virus infections of pregnancy}

The Herpes viruses include the cytomegalovirus (CMV), Epstein-Bart virus (EB), herpes simplex virus and Varicella-Zoster-virus (VZV).' These agents infect almost all humans at some point during their lives, the age of acquisition varying among populations. The herpes viruses are unique in that viral shedding may persist for weeks or months after the primary event. Latent infection is established after the primary infection and subsequently reactivation may occur, frequently subclinical. The major importance of the herpes viruses to the obstetric patient lies in their potential to infect the fetus or newborn resulting in either death or permanent neurological sequelae. Concerns about maternal well-being include systemic infection and complaints with medico-legal implications.

Some definitions which are helpful in understanding the literature regarding viruses are: primary infection the first exposure to the virus. Latent infection - the virus remains dormant in a host cell. Reactivation - reawakening of virus in the latent state to produce identifiable, infectious particles; this occurs spontaneously or as a result of external stimuli. Recrudescence - reactivation in the sensory ganglion to produce a skin or mucous mernbrane lesion in the corresponding dermatome. Recurrence - the presence of the infectious virus in the peripheral tissue but without a clinical lesion (e.g., viral shedding) ${ }^{2}$ 